\title{
摂食・曣下障害と言語治療
}

\author{
清水 充子
}

要 約：言語治療士が攝食・臙下障害のリハビリテーションに携わる意義を述べた，摂食・ 曣下障害は中枢・末梢の問願に起因し, 多くの場合コミュニケーションの問題を併せ持ってい る. 言語治療士は, 捸食・嬹下の機構に関する器官の解剖生理に詳しく, 発達・認知・心理的 背景など高次脳機能的な側面との関連を踏まえて, 訓練プログラムを立案, 実行できる立場に あると考えられる. 米国ではこうした観点から, ST によるアプローチが 1980 年代以降活発に 展開されている．続いて諸外国でもアプローチを進める動きがみえている.わが国でのアプロ ーチ 1 例として, 埼玉県総合リハビリテーションセンターでの摂食・臙下障害へのアプローチ を示した。過去 2 年間に ST に評価・訓練の依頼を受けた新規入院患者 295 例のうち，54\%に 評価あるいは評価後訓練を行った。また，外傷性脳損傷による慢性期重度嬹下障害の 1 例に対 する約 1 年間の訓練経過を報告した。

索引用語：捸食・曣下障害, 言語治療, 臙下訓練, 外傷性脳損傷, リハビリテーション

\section{A Therapeutic Approach to Dysphagia as an Aspect of Speech Therapy}

\author{
Mitsuko Shimizu
}

\begin{abstract}
The significance of the role of speech therapy in the rehabilitation of dysphagic patients is reviewed. Dysphagia is caused by diseases of the central or peripheral nervous system, and accordingly many dysphagic patients also exhibit difficulties in communication.

Speech therapists have a wealth of knowledge regarding the anatomy and physiology of the organs for swallowing. They are also in a suitable position to devise and carry out a treatment program from developmental, cognitive and psychological perspectives, as well as taking higher brain functional effectiveness into consideration. Recent rehabilitation treatment for dysphagic patients at the Saitama Prefectural Rehabilitation Center is reported.
\end{abstract}

Key words : dysphagia, treatment, speech therapy, swallowing therapy, traumatic brain injury, rehabilitation

\section{はじめに}

近年, リハビリテーション (以下リハ) 領域で摂食・ 嬩下障害に対するアプローチが注目されている。複数 の機構に現れる問題への対応として, 複数のスタッフ
による多角的なアプローチの重要性が叫ばれてい る ${ }^{1,2)}$. そのような中で, 口腔周辺の器官の運動障害や コミュニケーションを扱う言語治療士（Speech Therapist : ST) も，そのチームの一員として参画すること が多くなっている3).そこで, 言語療法および摂食・臙

埼玉県総合リハビリテーションセンター言語科： 7362 上尾市西貝塚 148-1

Saitama Prefectural Rehabilitation Center : 148-1, Nishikaizuka, Ageo-shi, Saitama 362

原稿受理：1997 年 8 月 5 日 
下障害へのアプローチの概観および実際例を示し, ST が捸食・曣下障害にアプローチする意義を考察する。

摂食・嚥下の機構とコミュニケーション

摂食・臙下に関する機構は，中枢および末梢の精巧 な機能連絡によって制御されており，食物を認知する ところから始まるその運動は, 発声発語器官をほぼ共 有して遂行される。

一方, 他者との交信活動の多くを占める音声言語に よるコミュニケーションは, 大脳レベルでの思考や言 語が, 呼吸・発声・構音運動を通して表現される。一 連の行動は対象となる事物や人を認知することから始 まり,それらとの相互作用で展開して行く活動である.

また，捸食・臙下の遂行は生命維持に不可欠な活動 であり,コミュニケーションを図り社会生活を送るこ とと同様，人間として生きる価値を保障し，ある時は 付加価值までも求める重要な活動である.

以上のように捸食・曣下およびコミュニケーション の活動は多くの器官を共有し, また, 機能的に関連し あいながら遂行される.さらに双方とも生命の誕生以 降, 認知・運動の発達によって達成されて行くもので ある。

\section{ST による摂食・嚥下障害へのアプローチの意義}

言語療法の対象となる障害は, 失語症, 運動障害性 構音障害, 音声障害, 言語発達遅滞, 口蓋裂言語など, 中枢から末梢までの発声発語に関する機構のいずれか に問題の起こった障害である(図 1 )。つまり, 中枢お よび末梢の問題に起因する発声発語器官の機能障害や コミュニケーション障害にアプローチするSTは，捸 食・曣下の機構に関する器官の解剖生理に詳しく, 発 達・認知・心理的背景など高次脳機能的な側面との関 連を踏まえて，訓練プログラムを立案し実行できる立

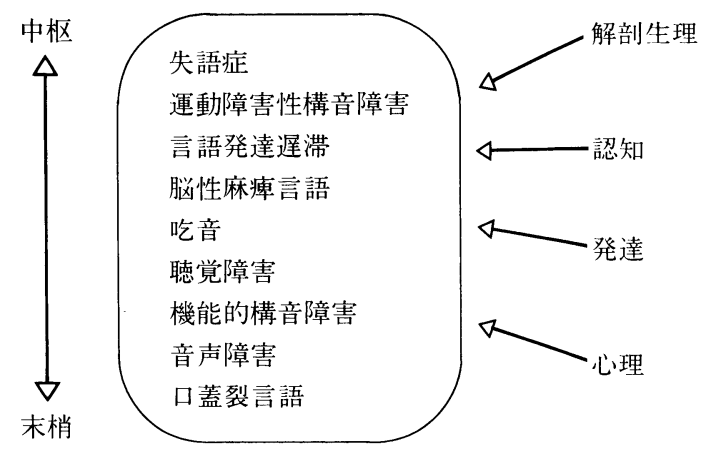

図 1 言語療法の対象
場にあると考えられる。

また，特に脳卒中・頭部外傷など中枢性の障害に起 因する摄食・䁵下障害例では, 機能的な訓練に加えて 食物形態や攝食方法の工夫や環境調整によって問題を 軽減させる働きかけも重要である．ST はこれらの患 者の状況を綿密に観察し, それぞれの個性に合わせた 指導・訓練を行うことが可能な立場にある.さらに， 家族やその他の介護者, 看護婦保健婦らへの指導も行 うことができる。

\section{諸外国における ST による捸食・嚥下障害への アプローチ}

米国ではこうした観点からST によるアプローチが 1980 年代以降, 活動に展開されている. American Speech-Language-Hearing Association (ASHA ; ア メリカ聴覚言語士協会) の調査によると, 1994 年には 聴覚障害を除く言語療法に携わるST の $42 \%$ が曖下 障害を取り扱っているという結果がでている4). また, この分野でのSTの役割の規定は 1988 年より The Joint Commission for Accreditation of Health and Human Services (JCAHO) や The National Institutes of Health（NIH）によってなされ，これを受け て 1990 年には教育的なカリキュラムの提案を ASHA が行っている5). 教科書も 1980 年代より Steefel $^{6)}$, Logemann ${ }^{7)}$, Groher ${ }^{8,9)}$ らよって著されている.

海外の状況を概観するために, IALP 国際音声言語 医学会での状況をみると, 1992 年の第 22 回学会には, 摂食・愳下に関する発表演題は 1 題であったが, 前回 の 1995 年には, 特別講演の 1 題に Logemann による “Dysphagia : Evaluation and Treatment”と題した講 演 ${ }^{10)}$ があった. 評価・訓練アプローチ全体を積極的に表 現した印象深いものであった。一般演題も 6 題, 1 セ ッションが設けられていた。海外では, 確実にアメリ カに続いてアプローチを進めて行く働きがみえ始めて いる印象である。

\section{捸食・嚥下運動とその障害}

次に，攝食・噁燕下の運動を概観する。曣下運動はそ の活動の部位により通例，口腔期(第 1 期), 咽頭期 (第 2 期)，食道期(第 3 期）に分けられる.さらに Leopold は, 障害学およびリハビリテーションの観点から嚥下 をより広く攝食行為としてとらえた方が問題点を整理 しやすいとし，口腔期・咽頭期・食道期の 3 期に先が けて先行期, 準備期の 2 期を加え， 5 期に区分して考 えることを提唱している ${ }^{11)}$.

つまり，先行期は食物を認知し，口まで運ぶ段階， 
準備期は食物を取り込み, 咀嚼運動によって食塊を形 成する段階, 口腔期は形成された食塊を咽頭へ送り込 む段階, そして, 咽頭期は嶼下反射が誘発され, 鼻咽 腔を閉鎖し咽頭通過するまでの段階, 食道期は蠕動運 動によって食道を通過して行く段階である.なお, 先 行期から口腔期までは随意的な運動機能で, 咽頭期以 降は反射的に運動が起こって行く過程である. 摂食・ 嚥下障害は，これらの機構のいずれかに障害が生じた 場合に発現する。

\section{捸食・嚥下障害の原因と対応}

次に, この攝食・讌下障害の原因と対応, さらに ST のアプローチの位置づけを確認する，摂食・瞹下障害 の原因はその背景から器質的障害, 機能的障害に大別 される ${ }^{12)}$.また,これら双方の要因を併わせ持つ発達障 害によるものがある。

器質的障害としては, 口腔・舌・咽頭などの腫場, 外傷, 多発性神経炎など炎症によるもの, 食道炎, 食 道狭窄によるものなどがある。機能的障害としては, 脳血管障害, 頭部外傷, 脳腫瘍, 多発性硬化症, 筋萎 縮性側索硬化症, 春髄小脳変性症などの神経・筋疾患 によるものなどがある．精神・運動発達遅滞によるも のも発達に即した対応によって, 機能向上を図ること が望め, 見逃すことはできない対象である ${ }^{13)}$.

これらの障害に対して, 運動機能的訓練, 患者本人 や家族に対しての対応の工夫指導, 環境調整を行い, 日常的な達成を確認して行くことがリハビリテーショ ンとしての対応である。
摂食・嚥下障害へのアプローチ一埼玉県総合リハ ビリテーションセンターにおける実際例—

\section{1. 言語治療の対象症例}

わが国でのアプローチの 1 例を紹介する，埼玉県総 合リハビリテーションセンターは 1994 年 7 月から病 院化（120 床）した。以来 2 年間にST に評価・訓練の 依頼を受けた新規入院患者 295 例への臨床内訳は次の 通りである（図 2 ）。

失語症, 高次脳機能障害に対してのみアプローチし た例は $46 \%$ ，摂食・曣下障害の疑いがあり何らかの評 価を行った例は $54 \%$ であった。評価後摂食・藇下訓練 を行ったのは全体の $31 \%$ ，90例であった.

この 90 例を原因疾患別にみると, 頭部外傷 4 例(年 齢は 20 歳から 24 歳で, 発症からの経過は平均 27.8 力 月), 神経疾患 9 例 (年歯令は 61 歳から 78 歳で, 発症か ら平均 11.2 力月), 最も多い対象は脳血管障害による もので, 77 例 (年齢は 30 歳から 89 歳で, 発症からの 経過は 7 日から 25.6 力月, 平均 6.8 力月) であった。 脳血管障害による症例では $27 \%$ に失語症や高次脳機 能障害が合併していた。

\section{2. 評価・診断・訓練の流れ}

これらの症例に対する, 評価, 診断, 治療の流れを 示す (図 3 )。まず，医師の診察により問題が明らかに 認められる場合, あるいは疑われる場合に, 詳細な評 価のオーダーが ST に出される. ST は口腔や摂食の 機能について評価し医師に報告する。その結果によっ て必要な場合は医師, 放射線技師, ST, 看護職, 栄養 士，理学療法士 (physical therapist : PT) の協力に よって, videofluorography (以下VF) を行い, これ らの検査結果から診断がなされる，そして，必要に応

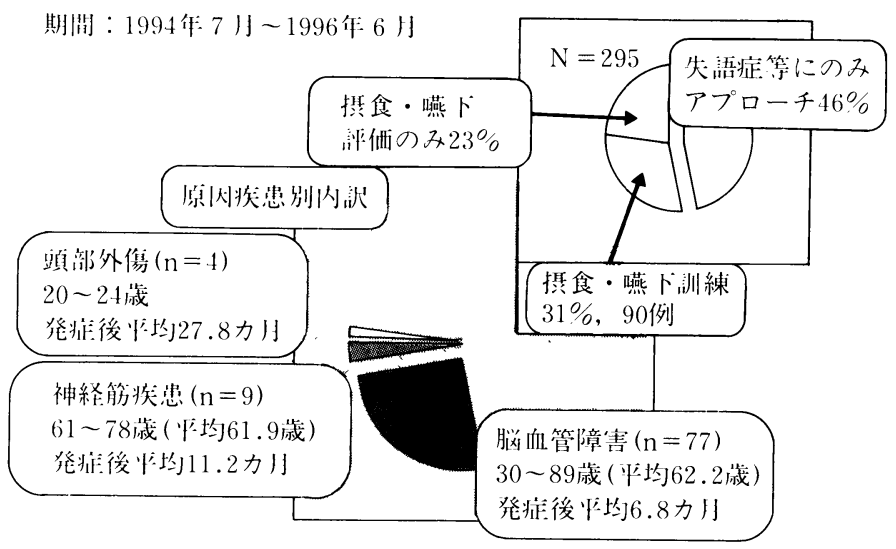

図 2 埼玉県総合リハビリテーションセンターにおけるアプローチ 


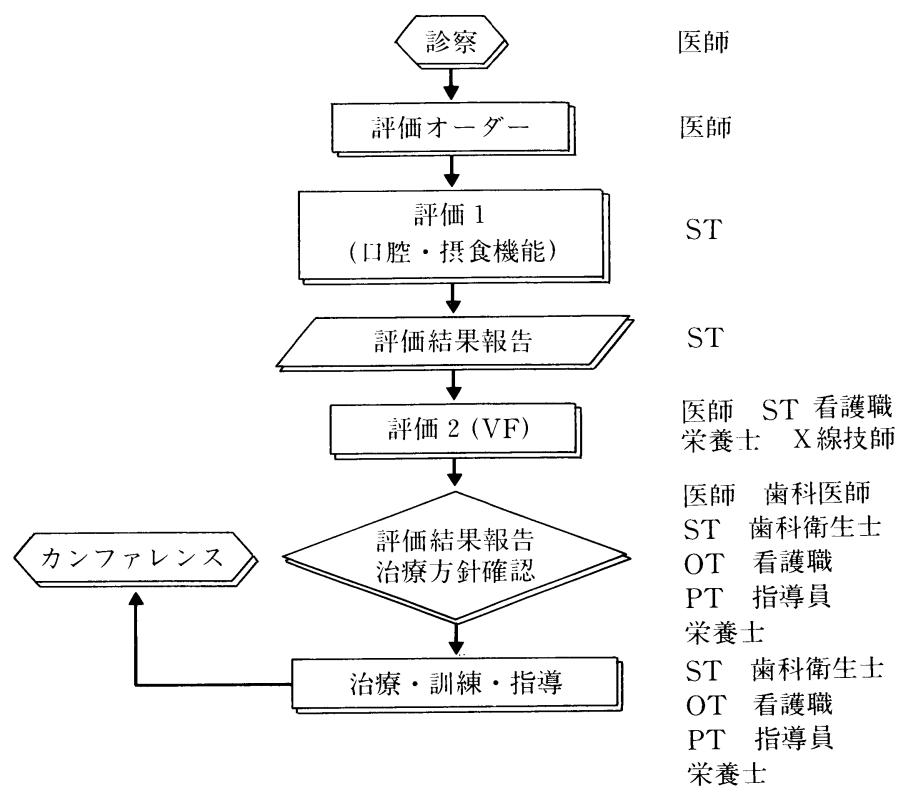

図 3 摂食・曣下障害の評価・診断・訓練の流れ

じて歯科医師, 歯科衛生士, 作業療法士 (occupational therapist: OT)が加わって方針を確認し, 治療, 訓練, 指導を行う。アプローチを続ける間には定期的にカン ファレンスを行い，方針確認と訓練内容の更新などを 行う.

\section{3. アプローチの内容}

次にアプローチの内容を述べる(図 4 ). まず評価で あるが, 全身状態のチェック, 口腔・咽頭・喉頭など の摂食・嬩下に直接関係する運動機能とそれらの器官 の感覚, 食物を口へ運ぶ上肢の機能, 体幹を支える機 能, さらにそれらの連合した運動によって達成される 呼吸・発声・構音の状態を評価する.また, 摂食・嬹 下の基礎的な準備として, 歯科的なアプローチ, つま り, 歯牙・咬合・義歯の状態, 口腔衛生の問題も対応 が必要である，以上の基盤に立って摂食行動が行われ るが，摂食のペースや一口量の調整など，患者自身の 摂食行動も評価する，可能な場合はVFにて誤嚥の有 無を確認する。なお，これらの評価はそれぞれの専門 職によって行い, 結果を統合して治療方針が立案でき ることが望ましい.

以上の評価の結果に基づいて行う訓練は, 食物を用 いずに行う間接的訓練と, 実際に食物を用いて行う直 接的訓練を，段階に応じて行う（図 5 )。

間接的訓練は，口腔清拭，口腔衛生指導を行い，口 腔内の感覚向上や，唾液分泌の適正化を図る. その上

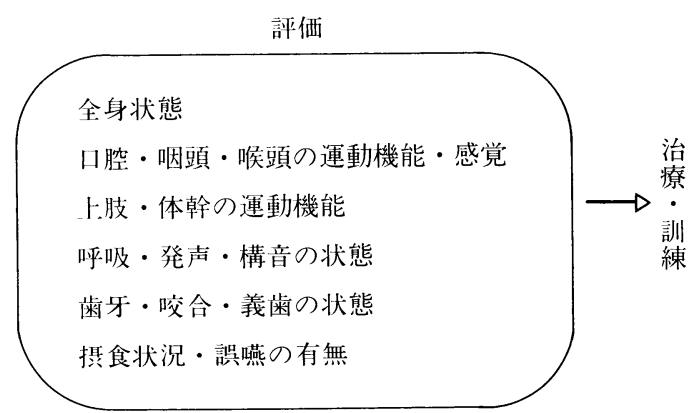

図４摂食・鯃下障害へのアプローチ

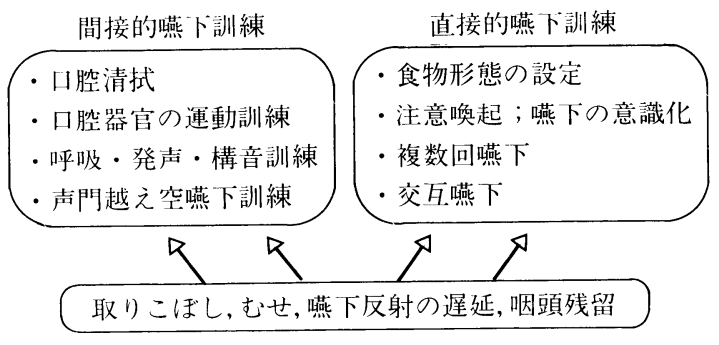

図 5 摂食・嶼下訓練

で口腔器官の運動訓練, 呼吸発声訓練, 声門越え空嬩 下訓練などを行う。その上に立って実際に食物を用い た直接的訓練を行う。直接的訓練は段階設定をした食 物を用いて，機能に合わせた安全な捸取を支えながら 
機能向上を図る訓練である。捸食・嶼下の注意喚起, 嚥下運動の意識化, 複数回曣下および交互嬩下による 咽頭のクリアランス誘導の励行などを行う.

\section{4 . 頭部外傷による慢性期嚥下障害に対する訓練}

次に訓練の実際例を示す，外傷性脳損傷による重度 曣下障害で, 発症から 1 年経過した時点から訓練を開 始し, 経口摂取にて在宅生活が可能となった例である。

症 例: 23 歳, 女性.

診 断：外傷性脳損傷, クモ膜下出血, びまん性軸 索損傷.

脳病巣：大脳皮質萎縮, 脳室拡大, 下部脳幹おょび 小脳底部萎縮。

現 症：四肢麻痺, 失調症, 曣下障害, 拘縮, 認知 記憶障害, 行動異常.

現病歴：1993 年 9 月交通事故により受傷. 2 力月間 の意識レベル低下期間を経て運動リ八開始. 7 力月後 よりうなづきなどによる意志疎通可能となり，11 カ月 半経過した 1994 年 8 月に当センターへ転院.

訓練開始時評価：栄養摄取方法は経鼻的経管栄養 (nasogastric tube feeding: 以下 $\mathrm{N}-\mathrm{G}$ 法).

発声発語器官機能は口唇, 舌, 煩, 顎, 軟口蓋の筋 力低下, 運動範囲・スピードの減少, さらに失調症状 により運動の巧緻性低下が顕著であった。また, 舌に は知覚過敏が認められた。嚥下機能は, 口腔器官の運 動機能障害に加えて催吐反射, 與下反射が減弱し, 流 涎が多量にみられた. 後傾 45 度の水の試飲検査では, $3 \mathrm{cc}$ でむせなく曣下可能, $5 \mathrm{cc}$ ではむせが認められ た. 誤與防止のため, 気管切開孔に内筒式カニューレ を装着, 口腔からの呼気流出困難で発声は不可能であ った. 運動機能的には体幹・頸部の筋の緊張低下と支 持性が弱く, 座位姿勢保持が不可能であった. 見当識, 認知記憶障害重度, さらに, 不安, 抑栕が強く病棟看 護職への訴えが昼夜を問わず非常に多く認められた。

コミュニケーションはイエス・ノー反応が辛うじて 可能であったが, 注意, 発動性低下が著しく, コミュ ニケーション場面への適応は不良であった。文字盤や コミュニケーションカードなどの補助手段も, 四肢体 幹, 視覚などの問題から使用困難であった。

経 過：訓練経過を, 栄養捸取方法の改善に則して 述べる.

第 1 期：間接的臙下訓練のみ $(\mathrm{N}-\mathrm{G}$ 法のみ；約 5 週 間).

コミュニケーション方法の開発，訓練体制を設定・ 導入した期間である. 心理的な不適応状態に対して, 24 時間接する看護職を中心に, 医師, PT, OT, ST の スタッフ間で情報を伝え合い, 本人のペースに合わせ
て対応するように努めた.ST としては, 現症と訓練目 的の理解を促しコミュニケーションの確立を図った上 で，嚥下機能改善訓練を開始した。まず，長期臥床に より不良であった口腔衛生の管理を開始し, 知覚過敏 に対する脱感作, 口腔運動, 唾液嬩下などの間接的訓 練を実施した。開始から約 1 力月を経てリ八訓練に適 応できた。

第 2 期：直接的嬩下訓練開始（N-G 法-間欠的口腔 一食道経管栄養 (intermittent oro-esophageal tube feeding, OE 法) 併用，約 6 力月間)

約 1 力月経過し, 心理的安定がみられた時期にVF を実施した。 その結果, ゼリーで口腔内移送, 保持と もに不良で喉頭挙上遅延が認められるものの, 液体よ りはスムーズで誤嚥はみられないことを確認した。そ こで,これまでの間接的訓練に並行して, 直接的訓練 を開始した.VFで安全確認できた条件,つまりベッド 上後傾 75 度で頸部を起こす姿勢で，一口量を $2 \mathrm{cc}$ 程 度とし, 取り込みのタイミングに留意して行った。開 始当初は $1 \sim 2$ 口で疲労がみられたが， 3 週目より 10 口（市販のゼリー $100 \mathrm{~g}$ の約 $1 / 2$ 量）を 15 分で摂取, 1 力月目に $100 \mathrm{~g}$ 全量を 45 分で摂取, 3 力月目で 20 分で捸取可能となった。

栄養攝取は, N-G 法に併せて間欠的口腔一食道経管 栄養 OE 法により捸取することとした。訓練開始から 3 力月経過時には $\mathrm{OE}$ 法の定着をみたため, 間接的訓 練を積極的に行う方針で, N-Gチューブを抜去した。

口腔運動範囲が徐々に拡大し, 知覚過敏は減少, 㱕 下運動では口腔内移送向上, 䵐下反射も確実に生起す るようになった。

第 3 期：一部経口摂取（ヨーグルト・ゼリー）と $\mathrm{OE}$ 法併用期 (約 2 力月間).

7 力月経過時, 2 回目の VF を実施し, ゼリー, 液 体とも喉頭挙上遅延は著しいものの, 口腔内移送に若 干の改善がみられ, 姿勢を保持して $5 \mathrm{cc}$ までの少量ず つの捸取であれば誤曣はみられないことを確認した。 そこで, 食形態を一段階上げ, ゼリー, プリン, ヨー グルト摂取を 1 日 1 回昼食時に開始した。むせ, 誤嬿 がときどきあり, 姿勢, 一口量, 意識集中に注意が必 要であったが, 市販のヨーグルト 1 カップを約 20 分で 攝取できるようになった。 同時期に気管切開孔カニュ ーレを抜去したが，長期間気管切開孔から呼吸してい たため, 口呼吸が不可能であった。発声を目標とした 呼吸訓練を, 経口的な腹式呼吸から促した. 発声は不 可能であった。

第 4 期：経口摂取確立期 (訓練開始から 10 力月目以 降） 
10 力月経過時の VF で, 後傾 75 度, 頸部屈曲位に て, ゼリー, ペーストとも喉頭挙上遅延認めるも誤嬹, 喉頭蓋谷・梨状陥凹への残留のないことを確認, 翌日 よりペースト食を開始した. 全介助にて摂取し, 姿勢, 濃度, 一口量, 本人の意識集中に配慮が必要であった が, 誤臙は徐々に減少した。ベッド脇に, 介助者への 注意書きを貼るなど，統一した介助ができるように工 夫した. 11 力月経過時よりペースト食自己摂取を開始 した.ムセが介助時より少なく, 姿勢保持はセッティ ングの仕方により安定した。食形態や献立内容につい ては栄養士の協力を得て食形態を適宜工夫し, 退院前 には母親に調理方法を含めた栄養指導を行い，12 力月 経過時退院となった。

退院後は, 本人のために新築した住居で, 母親作成 のペースト食を完全に自己摂取している。退院後 6 力 月経過時には，スティック状のスナック菓子が摄取可 能となっている.

コミュニケーションについては, 文字盤の使用を経 て, 退院後にトーキングエイドが使用可能となった。 手指の巧緻性, 視覚的な問題の軽減がみられ, 使用可 能となったものである。

なお，退院後は家庭医の往診，リ八医の診察，PT， ST 訓練を継続し, 退院後 1 年 2 力月を経過した現在, 肺炎など誤嚥によると思われる症状の既往は認められ ない.

\section{アプローチのまとめ (図 6 )}

訓練は約 1 年間という長期の入院での集中的なアプ ローチが必要であったが, コミュニケーションのサポ 一トを支えに，本人および家族に現症と訓練方針の理 解を促し，臙下の機能については，間接的訓練による 口腔咽頭機能の改善を基盤に直接的訓練を行った. 直 接的訓練は, VFにて安全を確認した方法 (形態, 量, 姿勢) で細かい段階設定の上に行った．また，段階に

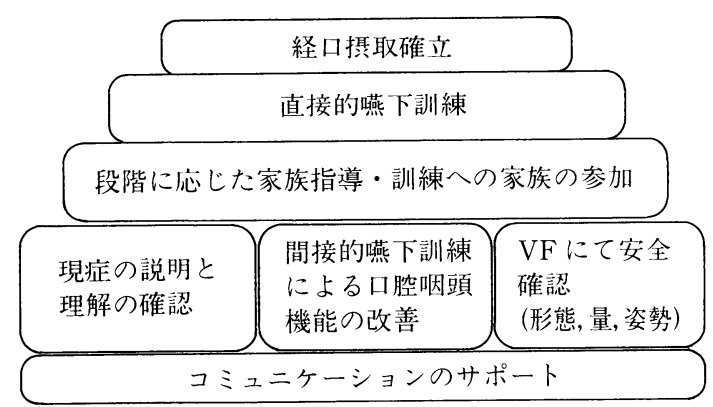

図 6 アプローチのまとめ
応じた家族指導を行い, 入院中も家族の訓練参加を促 したことも，在宅生活への移行を円滑にしたと考えら れる.これらの総合的な効果により改善を導いたと考 える。

\section{摂食・嚥下障害へのリハアプローチの要点}

最後にアプローチ上の要点を述べる，まず，適切な 評価によって, 先行期〜咽頭・食道期のどの期に問題 があるのか, その問題の背景は何か, またそれらが複 合して問題を重篤化させていることはないかなどを明 確にする。そして, 問題点の改善のための訓練プログ ラムを立案し訓練を行う。訓練実施中は経過に応じて 再評価を行い，プログラムを更新する（図 7 )。

また，訓練の実践にあたっては，リスクの管理と フォローアップを綿密に行うことが肝要である.さら に, 複数の関連する問題を合わせ持ち, 様相が多岐に わたる摂食・鷬下障害へのリハにおいては, 改善のた めの働きかけも複数の視点からの実践が必要である. 図 8 に示すような複数の専門職による働きかけと, そ れぞれの専門性に立脚した上での連携が大切である. 複数のメンバーで, 多角的に捉えて行くチームアプロ 一チをすることにより問題解決が図られ, 目標の達成 度を向上させることができると考えられる。ささらにそ の実践を積み重ねることで，より的確な方法が解明さ れて行くと考えられる.

\section{ま と め}

中枢から末梢の問題に起因する摄食・嚥下障害に対 するリハビリテーションに, ST が携わる意義を述べ た. 関連領域の専門職との連携をとり, 症例の心理・ 社会的な背景へのアプローチも視野に入れる実践を通 して改善過程の背景を検証することにより，的確な訓 練方法が確立されて行くと思われる.

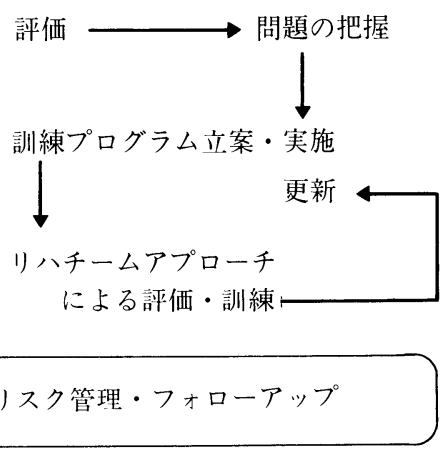

図 7 摂食・臙下障害へのアプローチの要点 


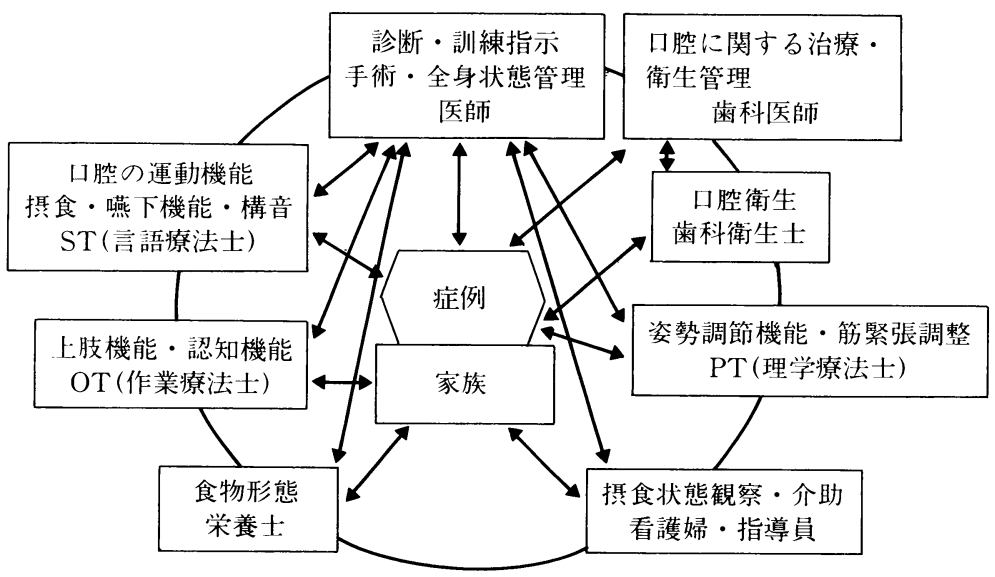

図 8 摂食・臙下障害に対するチームアプローチ

\section{文献}

1）藤島一郎：チームアプローチによる曣下障害の基 礎訓練と捸食訓練. 第 33 回日本リハビリテーショ ン医学会学術集会集録集, 68 頁, 1996.

2）藤谷順子：チームワーク. JJN スペシャル， 52 , 攝食・嬹下障害リハビリテーションマニュアル(才 藤栄一他編), 医学書院, 東京, 89-91 頁, 1996.

3）矢守麻奈：言語療法における咀下障害への取り組 み. 総合リハ, $23: 299-304,1995$.

4) American Speech-Language-Hearing Association : 1994 Omnibus Survey Facts, January 1995.

5) American Speech-Language-Hearing Association : Knowledge and skills needed by speech/ language pathologists providing service to dysphagic patients/clients, ASHA, 32 : 2-12, 1990.

6) Steefel, J. S. : Dysphagia Rehabilitation for Neurologically Impaired Adults. Charles C. Thomas, Springfield, 1981 (柴田貞雄 (監訳)，矢 守 茂, 矢守麻奈 (訳) : 曣下障害のリハビリテー ション一訓練と食事計画の実際, 協同医書出版, 東京, 1988)

7) Logemann, J. A. : Evaluation and Treatment of Swallowing Disorders. Pro-ed, Austin, 1983.

8) Groher, M. E. : Dysphagia : Diagnosis and Management, Butterworth, Stoneham, 1984 （塩
浦正男, 藤島一郎(訳)：嚥下障害一その病態とリ ハビリテーション, 医歯薬出版, 東京, 1989)

9) Groher, M. E., Smith, W. A., Bass, N. H., et al. : Dysphagia : Diagnosis and Management Second Edition, Butterworth-Heinemann, Stoneham, 1992 （藤島一郎（訳）：嚥下障害一その病態 とリハビリテーション, 第 2 版, 医歯薬出版, 東 京, 1996)

10) Logemann, J. A. : Dysphagia : Evaluation and Treatment. Foria Phoniatr Logop, 47 : 140-164, 1995.

11) Leopold, N. A., Kagel. M. C. : Swallowing ingestion and dysphagia. Arch. Phys. Med. Rehabil., 64 : 371-373, 1983.

12）藤島一郎：脳卒中の掑食・臙下障害, 医歯薬出版, 東京, 2 頁, 1993.

13）金子芳洋：心身障害児における捸食機能の異常. 食べる機能の障害一その考え方とリハビリテーシ ヨン (金子芳洋), 医歯薬出版. 東京, 43-85 頁, 1987.

14）矢守麻奈：曣下障害. 言語聴覚療法一臨床マニュ アル (日本言語療法士協会)。協同医書出版社, 東 京, 225-239 頁, 1992.

別刷請求先： $\mathbf{T} 362$ 上尾市西貝塚 148-1 埼玉県総合リハビリテーションセンター言語科 清水充子 